DOI: 10.15393/j9.art.2019.6462

УДК 821.161.1.09“18”

Стефано Алоэ

Университет Вероны (Università di Verona)

(Верона, Италия)

stefano.aloe@univr.it

\title{
«Это не просто поэмы...»: \\ нескодько заметок на полях письма \\ Ф. М. Достоевского А. Н. Майкову от 15 (27) мая 1869 года
}

\begin{abstract}
Аннотация. В письме из Флоренции от 15 (27) мая 1869 г. Ф. М. Достоевский сообщает Аполлону Майкову целый ряд своих идей, касающихся как поэтики, так и идеологии. Письмо посвящено, в частности, таким темам, как поэзия и поэтические жанры; основные точки русской истории и проблемы ее освещения; атеизм и христианство, ставшие в то время центром нового замысла писателя. Внимание автора статьи сосредоточено на содержащейся в письме концепции поэзии и в особенности на трактовке Достоевским повествовательной и дидаскалической природы жанра «поэмы». Другой, связанный с предыдущим, важный аспект анализа: исследуется то, как несостоявшийся поэт Достоевский создает оригинальную нарративную фигуру «поэта-повествователя» в «квазихудожественном» описании поэтических произведений - подобно его персонажу Ивану Карамазову, рассказывающему сюжет «поэмы» о Великом Инквизиторе. Оригинальность этой фигуры связана с характерным для Достоевского способом творческой разработки идей и замыслов. В письме Майкову, как и в пересказе Иваном «поэмы» о Великом Инквизиторе, отражаются приемы крайне сжатой, аллюзивной манеры творческого процесса, разработанной Достоевским в подготовительных тетрадях.
\end{abstract}

Ключевые слова: Ф. М. Достоевский, А. Н. Майков, нарратология, эпистолярный жанр, Великий Инквизитор, поэтические жанры

Об авторе: Алоэ Стефано - $\mathrm{PhD}$, профессор славяноведения и русской литературы, Университет Вероны (37129, Италия, г. Верона, Via San Francesco, 22)

Дата поступления: 18.02 .2019

Дата публикации: 09.09.2019

Для цитирования: Алоэ С. «Это не просто поэмы...»: несколько заметок на полях письма Ф. М. Достоевского А. Н. Майкову от 15 (27) мая 1869 года // Проблемы исторической поэтики. - 2019. - Т. 17. - № 3. - С. 86-105. DOI: 10.15393/j9.art.2019.6462

(c) С. Алоэ, 2019 
B есной 1869 г. Ф. М. Достоевский, вопреки своим намере-

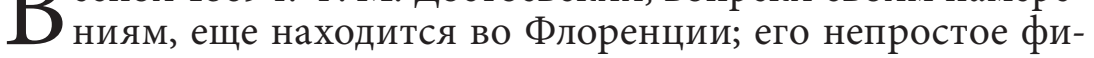
нансовое положение все менее располагает к восприятию красот итальянского города. Но неудобства и утомляющая нехватка денег, если и отражаются на деятельности писателя, то исключительно на его творческой активности и стремлении выйти из затруднительного положения, о чем свидетельствует обширная переписка с многочисленными адресатами. Одним из ближайших в этот период является поэт Аполлон Майков (о тесных личных и творческих отношениях Достоевского с братьями Майковыми см. [Седельникова: 65-93]).

Сосредоточим свое внимание на объемном письме от 15 (27) мая 1869 г., в котором Достоевский выражает целый ряд убеждений по поводу его понимания поэтики литературы, а также убеждения идеологического характера. Письмо касается, в частности, таких тем, как поэзия и поэтические жанры, признание основных моментов русской истории и утверждение их ключевого значения для патриотического сознания народа, атеизм и христианство, ставшие в те месяцы центром нового творческого замысла писателя. Не только высказанные им идеи, но и сама форма, в которой он их подает своему адресату, дают нам материал для размышления над некоторыми особенностями поэтики Достоевского.

Сразу же после вступительных фраз об исключительности дружбы с Майковым Федор Михайлович напоминает ему одну из тем другого своего письма, написанного тому же Майкову «ровно год назад», а точнее - 21-22 марта (2-3 апреля) 1868 г., из Женевы:

«Ну так в этом письме, в конце, я писал к Вам, полный серьезного и глубокого восторга, о новой идее, пришедшей мне в голову, собственно для Вас, для Вашей деятельности (то есть, если хотите, идея пришла сама по себе, как нечто самостоятельное и для меня вполне целое, но так как сам себя я никоим образом не мог считать возможным исполнителем этой идеи, то назначил ее, в желаниях моих, для Вас, естественно. Так даже, что, может, она и родилась-то во мне именно, как я уже сказал, для Вас или, лучше сказать, нераздельно с образом Вашим как поэта)»1.

Новая идея должна представиться довольно значимой для Достоевского, раз она не изжила себя более чем за год, прошедший между двумя его письмами. В женевском письме он 
ее не оглашает, а только обещает изложить в будущем отдельно и подробно:

«У меня есть одна мысль, для Вас, но она требует особого изложения, в целом письме, а теперь некогда. Скоро напишу. Мысль эта по поводу Вашей “Софьи Алексеевны” у меня зародилась $<\ldots>$ Это не роман и не поэма. Но это так нужно, так будет необходимо, и так будет оригинально и ново и с таким необходимым, русским направлением, что сами ахнете! <...> ...это даже надо будет особой книгой издать, напечатав несколько отрывков предварительно, а книга должна будет разойтись в громадном числе экземпляров» (Д30; 28, 282).

Флорентийское письмо исполняет высказанное прежде намерение - «новая идея» излагается тут довольно пространно. Приведем «идею», предложенную Майкову, почти полностью, чтобы потом рассмотреть определенные ее детали:

«...идея моя состояла тогда в том (теперь я скажу только несколько слов про нее), что мог бы появиться, в увлекательных, обаятельных стихах <...> ряд былин (баллад, песней, маленьких поэм, романсов, как хотите назовите; тут уж сущность и даже размер стихов зависят от души поэта и являются вдруг, совершенно готовые в душе его, даже независимо от него самого...). Сделаю отступление значительное: поэма, по-моему, является как самородный драгоценный камень, алмаз, в душе поэта, совсем готовый, во всей своей сущности, и вот это первое дело поэта как создателя и твориа, первая часть его творения. Если хотите, так даже не он и творец, а жизнь, могучая сущность жизни, Бог живой и сущий, совокупляющий свою силу в многоразличии создания местами, и чаще всего в великом сердце и в сильном поэте, так что если не сам поэт творец (а с этим надо согласиться <...>, потому что ведь уж слишком цельно, окончательно и готово является вдруг из души поэта создание), - если не сам он творец, то, по крайней мере, душа-то его есть тот самый рудник, который зарождает алмазы и без которого их нигде не найти. Затем уж следует второе дело поэта, уже не так глубокое и таинственное, а только как художника: это, получив алмаз, обделать и оправить его. (Тут поэт почти только что ювелир.) Ну так вот, в этом ряде былин, в стихах (представляя себе эти былины, я представлял себе иногда Ваш «Констанцский собор») - воспроизвести, с любовью и с нашею мыслию, с самого начала с русским взглядом, - всю русскую историю, отмечая в ней те точки и пункты, в которых она, временами и местами, 
как бы сосредоточивалась и выражалась вся, вдруг, во всем своем целом. Таких всевыражающих пунктов найдется, во все тысячелетие, до десяти, даже чуть ли не больше. Ну вот схватить эти пункты и рассказать в былине, всем и каждому, но не как простую летопись, нет, а как сердечную поэму, даже без строгой передачи факта (но только с чрезвычайною ясностию), схватить главный пункт и так передать его, чтоб видно, с какой мыслию он вылился, с какой любовью и мукою эта мысль досталась. Но без эгоизма, без слов от себя, а наивно, как можно наивнее, только чтоб одна любовь к России била горячим ключом - и более ничего» (Д30; 29, $38-39)$.

С какими подробностями Достоевский описывает общую концепцию своих «былин» и краткий сюжет некоторых из них, для него особенно значимых, - тема, выходящая за рамки настоящей статьи. С ней связаны и позиции самого Майкова, выраженные им в предшествующих письмах Достоевскому (см. [Захарова: 71-283]). Вследствие этого можно утверждать, что отчасти эта концепция - плод совместных размышлений двух литераторов. Сосредоточим свое внимание на этой «новой идее», которую Достоевский - несмотря на декларированную потребность ясности и наивности - излагает в сложной и не совсем последовательной форме, особенно в силу отступлений, значение которых представляется, впрочем, важным не менее самой же изложенной сюжетной идеи.

Итак, можно резюмировать концепцию в следующих пунктах:

- необходимо выделить некоторые эпизоды (около десяти) из тысячелетней русской истории по принципу их значимости для судеб и духа русского народа и российского государства;

- изложить их в простых, всем и каждому доступных стихах в виде небольших поэм или «былин», в хронологическом порядке с древнерусского периода до предполагаемого будущего России.

Таким образом, независимо от структурной фрагментарности замысла получился бы, по мнению Достоевского, наделенный внутренней логикой и единством цикл небольших стихотворных произведений на историко-патриотические сюжеты, которые своей образцовостью могли бы способствовать самопознанию русского человека. О замысле некоторых 
конкретных эпизодов Достоевский пишет в продолжение своего письма, к чему мы вернемся позже - интерес представляет сам по себе предмет задуманного цикла.

Вначале уместно сосредоточить внимание на концепции поэзии, которая возникает из этих размышлений, и в особенности на трактовке писателем «поэмы» как жанра, в основном, повествовательного, имеющего, в том числе, дидаскалическую природу. Бросается в глаза тот факт, что для Достоевского теоретические и технические вопросы стихотворства стоят на заднем плане, в то время как большое внимание уделяется им повествовательным целям поэзии, эффекту ее воздействия на широкий круг читателей. Вполне последовательно по этому поводу сам Майков писал в одном письме Достоевскому 1868 г.: «Поэма наша - это романъ, и романъ не въ стихахъ. Поэмы то - вы пйшете»! (цит. по: [Захарова: 275])2 .

Поэтическая терминология Достоевского в вышеуказанном письме колеблется не только в том, что касается определения жанров, но и в восприятии метрики. Писатель говорит, что задуманные произведения могли бы получить название «былин $^{3}$ (баллад, песней, маленьких поэм, романсов, как хотите назовите)»; в дальнейшем тексте письма упоминаются еще и «былины в стихах», «поэмы», «баллады», «поэмы-былины», «стихи и поэмы, сравнительно короткие» (Д30; 29: 39). Из данного наблюдения следует, что жанровое дифференцирование не имеет для Достоевского принципиального значения, акцент ставится на повествовательных и стилевых характеристиках предполагаемых произведений: они должны быть «в увлекательных, обаятельных стихах» и представлять «не как простую летопись, нет, а как сердечную поэму, даже без строгой передачи факта (но только с чрезвычайною ясностию)», так как «эти поэмы все мальчики в школах будут знать и учить наизусть»; «это стихи и поэмы, сравнительно короткие», и «надо, чтоб поэмы были необыкновенной поэтической прелести» (Д30; 29: :41).

Особенно значимым нам представляется определение разницы между «сердечной поэмой» и «простой летописью», указывающее на общий тон и цели стихов. Они призваны быть способными довести до читателя понятный, ясный, но в то же время «сердечный», эмоционально насыщенный нарратив, избегая, с одной стороны, изысков элитарной поэзии, 
а с другой - сухой строгости «передачи факта» обычной хроники («летописания»). Таким образом выстраивается идея о компромиссе дидактической, по-школьному наставительной цели, с увлекательной. Сам Достоевский определяет цели жанра высоко эмоциональным высказыванием: «...это не просто поэмы и литературное занятие, - это наука, это проповедь, это подвиг» (Д30; 29; : 41).

Наука, проповедь, подвиг: мощный триптих знаменуется явно восходящим движением - это три этапа творческого роста, которые нельзя поменять местами. Особенный интерес представляет понимание Достоевским слова «наука», его соотнесенность с духовной сферой. Подобное употребление этого слова встречаем, например, в ранней повести «Хозяйка» (1847), в которой о главном герое Ордынове говорится:

«Может быть, в нем осуществилась бы целая, оригинальная, самобытная идея. Может быть, ему суждено было быть художником в науке. По крайней мере прежде он сам верил в это. Искренняя вера есть уж залог будущего» (курсив мой. - С. А.) (Д30; 1: 318).

Один из аспектов этого вопроса, так или иначе имеющий отношение к художественному замыслу, предложенному Майкову, состоит в том, что Достоевский склонен связывать понятие о науке с идеей о высокой телеологической концепции, все объясняющей на уровне «судеб», в сочетании исторического с метафизическим, и к тому же предполагающей скорее творческий, «художественный» подход, чем рационалистический. Если смутная идея Ордынова была связана с историей русской церкви, то в концепции, представленной Достоевским Майкову, речь идет «о будущей науке, об атеизме, о правах человечества, сознанных по-западному, а не по-нашему, что и послужило источником всего, что есть и что будет», и задумываемое произведение должно служить «великою национальною книгой» (Д30; 29; : 40-41).

При имеющихся отличиях, в том и другом случае заметную роль получает художественное воплощение великой, «научной», идеи. В своем творчестве писатель выражает стремление достичь уровня «проповеди», приблизиться к передаче самой Истины. Созданное по таким принципам произведение своей «сердечностью», а не «строгой передачей факта (но только 
с чрезвычайною ясностию)», способно служить такой «научной» цели познания мира и человека. Недаром достижение этого результата уподобляется религиозному «подвигу».

Пересказ высокого сюжета, великого замысла, становится, таким образом, самостоятельным творческим мотивом, фигурой внутреннего подвига писателя в драматичном поиске Истины и формы ее художественного откровения.

Именно в этом контексте уточняется смысл процитированного выше высказывания Достоевского о разных ролях «поэта» («как создателя и творияа») и «художника» («получив алмаз, обделать и оправить его <...> почти только что ювелир») - идеи, снова подхваченной писателем несколько лет спустя (в начале 1874 г.) в первых подготовительных тетрадях к роману «Подросток»:

«ЧТОБЫ НАПИСАТЬ РОМАН, НАДО ЗАПАСТИСЬ ПРЕЖДЕ ВСЕГО ОДНИМ ИЛИ НЕСКОЛЬКИМИ СИЛЬНЫМИ ВПЕЧАТЛЕНИЯМИ, ПЕРЕЖИТЫМИ СЕРДЦЕМ АВТОРА ДЕЙСТВИТЕЛЬНО.

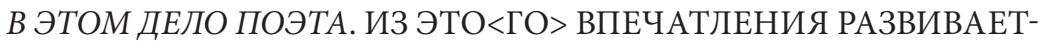
СЯ ТЕМА, ПЛАН, СТРОЙНОЕ ЦЕЛОЕ. ТУТ ДЕЛО УЖЕ ХУДОЖНИКА, ХОТЯ ХУДОЖНИК И ПОЭТ ПОМОГАЮТ ДРУГ ДРУГУ И В ЭТОМ И В ДРУГОМ - В ОБОИХ СЛУЧАЯХ» (Д30; 16: 10).

Если оба дела необходимы в творческом процессе, то главная роль остается за «поэтом», посредником между миром истины и рациональным восприятием реальности. Достоевский допускает, что творение уже существует до его воплощения в постижимом виде, а проблема «поэта»в том, как осуществить этот важный «гражданский» акт подачи творения, его «перевода» на язык человечества, чтобы оно приносило пользу, озаряло людей. В этом деликатном процессе писатель угадывает возможность признать чрезвычайное значение и самого акта «перевода», балансируя между ролями «поэта» и «художника»: другими словами, возможность передать творение не в завершенном, отшлифованном виде готового ювелирного изделия, а в его промежуточном состоянии, когда творение еще не утратило (ради эстетического совершенства) своей первобытной чистоты и энергии, отражения озаряющей его Истины. Из этого следует, что поэт для Достоевского - не просто автор стихотворных строк, а своего рода проповедник Истины, поэзия же - подвиг, идеал, 
к которому можно приблизиться только посредством прозы. Проза, таким образом, для Достоевского едва ли не единственный способ передачи поэзии! И настоящая поэзия выживает в прозаическом пересказе, как сфера божественного постижима только чувством, а передаваема лишь художественной метафорой или апофатическим погружением в умолчание.

В творчестве Достоевского самым совершенным воплощением мотива пересказа исконного сюжета является «поэма» Ивана Карамазова о Великом Инквизиторе, в которой пересказ представляется своеобразным вставным художественным жанром.

Перед тем как провести сопоставление «былины-поэмы» в письме Майкову с «поэмой» в последнем романе Достоевского, хочется подчеркнуть некоторое несоответствие в высказываниях писателя между столь глубокой концепцией творческих процессов и художественного акта и его восприятием поэзии как таковой. Как было отмечено нами, жанровое дифференцирование в целом не представляется писателю определяющим ${ }^{4}$. На первый взгляд, предложенные Достоевским жанры - «ряд былин (баллад, песней, маленьких поэм, романсов, как хотите назовите <...>)» - ведут к уже известным и довольно типичным для той эпохи опытам - историческим балладам или поэмам. Произведениями такого типа (на основе подобной «историко-философской» или «национальной» концепции) русская литература изобиловала и во времена Достоевского (см. среди прочих творения и самого А. Н. Майкова), и в более ранние периоды (достаточно будет упомянуть рылеевские «Думы»). Кроме того, идея представить ряд народно-исторических картин, через которые интерпретируются дух нации и / или суть всемирной истории, типична не только для русской, но и для европейской традиции. Главные ее образцы - хорошо известные Достоевскому «Чайльд Гарольд» Дж. Байрона и «Фауст» Й.-В. Гете (ср. [Иванов], [Paolini], [Загидуллина], [Бем], [Ковач, 1997] и др.). Повествовательная поэзия на основе исторического (часто патриотического) сюжета с авторскими попытками выделить ключевые моменты истории народа в цикле поэм или баллад - это явление, встречаемое во всех национальных литературах XIX в.

В частности, «всемирная история» посредством эмблематических эпизодов - амбиция не одного русского поэта. 
Достоевский с большой вероятностью мог в 1869 г. быть знаком с поэмой В. А. Жуковского «Агасфер» (или «Странствующий жид», 1852), имеющей структуру, близко напоминающую предложенную Майкову для цикла. Похожей структурой обладает и незаконченная поэма В. К. Кюхельбекера «Агасвер» (1832-1845) на тот же сюжет, знакомство Достоевского с которой, однако, в 1868-1869 гг. надо признать невозможным, так как она впервые опубликована в журнале «Русская Старина» в 1878 г. (т. 3, март, с. 403-462) под заглавием «Вечный Жид» (см. [Алоэ]). В поэмах Жуковского и Кюхельбекера история религии и диалектика веры и безбожия получают центральное место - так же, как это планирует Достоевский в письме Майкову:

«...перейти к изображению конца пятнадцатого и начала 16-го столетия в Европе, Италии, папства, искусства храмов, Рафаэля, поклонения Аполлону Бельведерскому, первых слухов о реформе, о Лютере, об Америке, об золоте, об Испании и Англии, - целая горячая картина, в параллель со всеми предыдущими русскими картинами, - но с намеками о будущности этой картины, о будущей науке, об атеизме, о правах человечества, сознанных позападному, а не по-нашему, что и послужило источником всего, что есть и что будет. В горячей мысли моей я думал даже, что не надо кончать былины на Петре <...>. Я бы прошел до Бирона, до Екатерины и далее, - я бы прошел до освобождения крестьян и до бояр, рассыпавшихся по Европе с последними кредитными рублишками, до барынь, $6<\ldots>$ щих с Боргезанами, до семинаристов, проповедующих атеизм, до всегуманных и всесветных граждан русских графов, пишущих критики и повести, и т. д. и т. д. Поляки бы должны были занять много места. Затем кончил бы фантастическими картинами будущего: России через два столетия, и рядом померкшей, истерзанной и оскотинившейся Европы, с ее цивилизацией. Я бы не остановился тут ни перед какой фантазией...» (Д30; 291:40-41).

«Фантастические картины будущего» также могут напоминать аллегорические фантасмагории XVIII в. (как, например, повести Вольтера) и романтизма (в русской литературе, например, в сочинениях О. Сенковского, В. Одоевского и того же B. Кюхельбекера). Тем не менее оставим в стороне, как второстепенный, вопрос о знакомстве Достоевского с тем или иным произведением с подобной повествовательной и концептуальной структурой; важно, напротив, заметить продуктивность 
самой структуры в русской культуре эпохи. Призывающий Майкова к оригинальности и новизне («так будет оригинально и ново»), Достоевский этим же проявляет в своих поэтических вкусах «неоригинальную оригинальность», повторяя в своих мечтаниях уже протоптанные пути. С духом и терминологией романтизма напрямую связаны его призывы к «восторгу», народности, «простоте и наивности»:

«...придется Вам вполне по силам сказать новое слово, Ваше новое слово! И потому смотрите на дело серьезнее, глубже и больше восторга. А главное - простоты и наивности больше. Да вот еще: пишите рифмой, а не старым русским размером. Не смейтесь! Это важно: теперь рифма - народна, а старый русский размер - академизм. Ни одно сочинение белыми стихами наизусть не заучивается. Народ уже не сочиняет песен прежним размером, а сочиняет в рифмах. Если не будет рифмы (и не будет почаще хорея) - право, Вы дело погубите» (Д30; 29.1: 42).

Предпочтение незатейливого хорея, самого популярного «народного» поэтического размера во всей Европе в течение целого века, так же показательно для довольно невнимательного отношения Достоевского к художественным сторонам повествовательной поэзии. Хорей - истинный балладный размер европейской поэзии, размер романтической народности и гражданских (вольнолюбивых, патриотических) стихотворений [Гаспаров: 68-70, 120-122, 175-176]. Ради хорея (и ради простонародности рифмы) писатель пренебрегает, принимая его за «академизм», возвращением к «старому русскому размеру», т. е. современными попытками воссоздания новых поэтических созвучий с русским фольклором и с древнерусской эпикой (былинами ${ }^{5}$, «ловом о полку Игореве»). История русской поэзии нам показывает, что дольнику и другим более или менее экспериментальным размерам было суждено сыграть главную роль в начале XX в., в то время как значение хорея до сих пор остается совершенно второстепенным. Другими словами, Достоевский, в поиске нового и оригинального слова, тем не менее оказался в данном случае вполне в ладу с преходящими модами позднего романтизма и с патриотическими веяниями целой Европы; его предложения о поэтическом восхвалении русскости сходятся, например, с результатами крайне посредственной и пафосно-риторической 
поэзии итальянского Рисорджименто (возрождения итальянской национальной идентичности) и прочих национальных движений эпохи.

В этом своем «неоригинальном поиске оригинальности» Достоевский сумел, тем не менее, быть крайне оригинальным, - только другим образом... Если его вкус сильно не отличается в данном случае от вкуса эпохи, то его способность предвещать достижения литературы XX в. сказывается в своеобразной, действительно новой манере трактовать романтическую тему незавершенного шедевра, тему невыразимого замысла. Не ставший поэтом (см. [Захаров, 2013]), Достоевский «изобретает» в письме Майкову «квази-художественное» описание вымышленных поэтических произведений, как сделает это его персонаж Иван Карамазов в переложении сюжета «поэмы» о Великом Инквизиторе 6 . Он таким образом создает своего рода «внутрижанровый экфрасис», особенность которого состоит в воспроизведении одного вида искусства в другом (напр., в литературе); происходит он внутри художественного произведения как такового, затрагивая самые механизмы наррации.

«Вообразите себе, что в третьей или в четвертой былине (я их в уме тогда сочинил и долго потом сочинял) у меня вышло взятие Магометом 2-м Константинополя (и это прямо и невольно явилось как былина из русской истории, сама собою и без намерения <...>). Вся эта катастрофа в наивном и сжатом рассказе: турки облегли Царьград тесно; последняя ночь перед приступом, который был на заре; последний император ходит по дворцу

(“Король ходит большими шагами”),

идет молиться образу Влахернской Божией матери; молитва; приступ, бой; султан с окровавленной саблей въезжает в Константинополь. Труп последнего императора отыскивают по приказанию султана в куче убитых, узнают по орлам, вышитым на сапожках. Святая София, дрожащий патриарх, последняя обедня, султан, не слезая с коня, скачет по ступеням в самый храм (historique), доскакав до средины храма, останавливает коня в смущении, задумчиво и с смятением озирается и выговаривает слова: “Вот дом для молитвы Аллаху!” Затем выбрасывают иконы, престол, ломают алтарь, становят мечеть, труп императора хоронят, а в русском царстве последняя из Палеологов является с двуглавым орлом вместо приданого; русская свадьба, князь Иван III в своей деревянной избе вместо дворца, 
и в эту деревянную избу переходит и великая идея о всеправославном значении России, и полагается первый камень о будущем главенстве на Востоке, расширяется круг русской будущности...» (Д30; 29: $39-40)$.

Это своего рода эксперимент фиктивного поэтического повествования, открывающий вопрос о художественной самостоятельности определенных приемов описания вымышленного или задумываемого произведения, что отсылает к жанру «фиктивных эссе», которые представляют собой рецензии на несуществующие произведения, практикуемые писателями второй половины XX в., такими как, например, Х.-Л. Борхес или С. Лем. Особенно заметно сходство с концепцией Борхеса, постулирующего существование всех произведений искусства в сфере идей и независимо от авторов, которым дана лишь роль «переписывать», оглашать уже готовые тексты (ср.: [Надъярных: 404-419]). Такая работа в поиске существующего уже in nuce (лат. «в зародыше») текста может стать сюжетом произведения, и само произведение быть косвенным отражением другого, более совершенного опуса. Так, в романе «Братья Карамазовы»:

«- Ты написал поэму?

- О нет, не написал, - засмеялся Иван, - и никогда в жизни я не сочинил даже двух стихов. Но я поэму эту выдумал и запомнил. С жаром выдумал» (Д30; 14: 224).

В. Н. Захаров обоснованно замечает, что «использование вставных жанров - характерное явление в поэтике Достоевского», и, основываясь на анализе частоты и разнообразия вставных повествовательных единиц в произведениях писателя, заключает, что романы Достоевского, вместе с «Дневником Писателя», составляют настоящую «энциклопедию жанров» [Захаров, 1997]. К этому можно добавить, что Достоевский не только блестяще усвоил уже существующие в романной традиции повествовательные структуры (как, например, рамочные композиции, рассказ в рассказе по образцу «Дон Кихота», раскрытие чужой рукописи и т. п.), но и дополнил их экфрастическим воспроизведением творческого замысла, не являющегося жанром как таковым, но отражающего «творческий процесс возникновения художественного произведения», - «жанром», суть которого в нарративе о творческой 
незавершенности, в энергетике диалектики состоявшегося и несостоявшегося. В результате, никогда не появившаяся поэзия «резонирует» экфрастически в романном (или эпистолярном) пересказе.

Сама по себе тема диалектики состоявшегося и несостоявшегося в искусстве заимствована Достоевским (как, впрочем, и Борхесом) у романтиков. Но между ними и романтиками есть существенная разница в концепции задумываемого: Достоевский, так же как и аргентинский писатель, работает над невоплощенным замыслом, будто бы он уже существовал как готовое произведение, отзвуки которого достигают «поэта». Эти отзвуки таким образом придают замыслу некую косвенную конкретику, в то время как для романтиков это всегда только фантастический мотив, функционально лишенный конкретных деталей, так что читатель узнает только суждения повествователя о ценности, невероятной глубине, красоте, оригинальности вымышленного произведения или замысла, без возможности «прикосновения» к этому прекрасному творению. Напротив, о творческих идеях Достоевского можно составить вполне реальное представление.

В этом отношении оригинальность Достоевского тесно связана с характерным для него способом творческой разработки идей и замыслов. В письме Майкову, как и в пересказе Иваном «поэмы» о Великом Инквизиторе, отражаются приемы крайне сжатой, аллюзивной манеры творческого процесса, разработанной Достоевским в подготовительных тетрадях. Сам по себе, особенно в зрелом творчестве писателя, «новый роман Достоевского оказался синтетическим жанром, способным поглотить любые художественные и нехудожественные жанры» [Захаров, 1985: 139]. В этом прослеживается процесс постепенного расширения возможностей романного выражения, литературным приемом которого становится включение элементов замысла и «творческой лаборатории» писателя. Два вполне оригинальных по жанровой характеристике произведения Достоевского, отражающие в своем названии идею записывания - «Записки из Мертвого дома» и «Записки из подполья», - и еще одно произведение - роман «Подросток» - основаны на нарративном эксперименте с «записками» главного героя. «Аркадий Долгорукий, - как отмечает B. Н. Захаров, - пишет нелитературную прозу, коверкает 
литературные красоты, сознательно избегает эстетического косноязычия, намеренно нарушает синтаксис литературного языка. Он подчеркнуто антилитературен в своих декларациях. В итоге неожиданный эффект: герой писал записки, а получился роман, роман в форме записок. Новый роман был открытием писателя» [Захаров, 2013: 387-388].

Черты записок, чуждые сложившимся стилю и языку художественной литературы, по-разному проявляются в творчестве Достоевского, в его непрекращаемом поиске выражения внутренней сути искусства - натуры «поэта». Паратаксис, цитаты, аллюзии, употребление настоящего исторического, плавный переход с косвенной на прямую речь, фиксирование точек зрения разных персонажей в одном непрерывном потоке: все это в главе «Великий Инквизитор» «Братьев Карамазовых» как бы переходит из записных книжек писателя в новую форму наррации, в которой иллюзия устного рассказа (или пересказа) пересекается с «импрессионистическим» эффектом импровизированного изложения некоего наброска:

«Действие у меня в Испании, в Севилье, в самое страшное время инквизиции, когда во славу Божию в стране ежедневно горели костры и

В великолепных автодафе

Сжигали злых еретиков.

$\mathrm{O}$, это, конечно, было не то сошествие, в котором явится Он, по обещанию своему, в конце времен во всей славе небесной и которое будет внезапно, “как молния, блистающая от востока до запада”. Нет, Он возжелал хоть на мгновенье посетить детей своих и именно там, где как раз затрещали костры еретиков. По безмерному милосердию своему Он проходит еще раз между людей в том самом образе человеческом, в котором ходил три года между людьми пятнадцать веков назад. Он снисходит на “стогны жаркие" южного города, как раз в котором всего лишь накануне в “великолепном автодафе”, в присутствии короля, двора, рыцарей, кардиналов и прелестнейших придворных дам, при многочисленном населении всей Севильи, была сожжена кардиналом великим инквизитором разом чуть не целая сотня еретиков ad majorem gloriam Dei» (Д30; 14: 226).

Создается что-то промежуточное между диегезисом и мимесисом, с постоянными скачками внутри и вне поля повествования (этому, в частности, способствуют метанарративные 
высказывания Ивана: «Он появился тихо, незаметно, и вот все - странно это - узнают Его. Это могло бы быть одним из лучших мест поэмы, то есть почему именно узнают Его», и т. п. - Д30; 14: 226). Альберт Ковач справедливо заметил, что «поэму Ивана несколько раз прерывает Алеша, так что в мифическом пласте устанавливаются опорные пункты реально-психологического пласта текста. Прямое назначение этих переплетающихся планов прежде всего конструктивное, с их помощью не только старший брат разъясняет младшему условность художественно-фантастической формы своей поэмы и проясняет смысл ее символов, но и сам писатель как бы демонстрирует силу своего искусства» [Ковач, 2008: 204]. Сплетение изложения сюжета поэмы с диалогом между братьями составляет таким образом элемент нарративной «трехмерности»: не только фантастический рассказ о Христе и Великом Инквизиторе приобретает жизнь, но одновременно складывается в "устных» комментариях и реакциях двух героев на рассказ и параллельный сюжет философского содержания [Сараскина, 1996]. Достоевский придает отзвукам прямой речи центральное значение и для воссоздания эффекта возникновения поэмы «здесь и сейчас»:

«Вот из толпы восклицает старик, слепой с детских лет: “Господи, исцели меня, да и я Тебя узрю”, и вот как бы чешуя сходит с глаз его, и слепой Его видит. Народ плачет и целует землю, по которой идет Он. Дети бросают пред Ним цветы, поют и вопиют Ему: "Осанна!" “Это Он, это сам Он, - повторяют все, это должен быть Он, это никто как Он” <...> Мертвый ребенок лежит весь в цветах. “Он воскресит твое дитя", - кричат из толпы плачущей матери. Вышедший навстречу гроба соборный патер смотрит в недоумении и хмурит брови. Но вот раздается вопль матери умершего ребенка. Она повергается к ногам Его: “Если это Ты, то воскреси дитя мое!” - восклицает она, простирая к Нему руки <...>. В народе смятение, крики, рыдания, и вот, в эту самую минуту, вдруг проходит мимо собора по площади сам кардинал великий инквизитор» (Д30; 14: 227).

Лаборатория писателя проявляется в законченном авторском тексте, сначала в личном письме, а в дальнейшем и в художественном произведении, демонстрируя таким образом проникновение в мир литературы того самого творческого импульса, из которого она и возникает. «Я бы не остановился тут 
ни перед какой фантазией...»: Достоевский преодолевает последние табу повествования. Уже «подполье» произведения и процесс его создания могут стать одновременно литературным средством и сюжетом, как будто само произведение было лишь отголоском другого, более истинного и совершенного творения.

\section{Примечания}

1 Достоевский Ф. М. Полн. собр. соч.: в 30 т. Т. 29. Кн. 1. Л.: Наука, 1986. С. 38. Далее ссылки на это издание приводятся в тексте статьи с использованием сокращения Д30 и указанием тома, книги (нижний индекс), страницы в круглых скобках.

2 Один интересный отклик о восприятии поэмы как прозаического жанра (точнее, как вида романа) встречается в подготовительных записях к «Подростку»: «Фантастическая поэма-роман: будущее общество, коммуна, восстание в Париже, победа, 200 миллионов голов, страшные язвы, разврат, истребление искусств, библиотек, замученный ребенок. Споры, беззаконие. Смерть» (Д30; 16: 5).

3 О ключевом и своеобразном значении этого термина у Достоевского В. А. Михнюкевич заметил: «Писатель мог использовать народный термин для целей метафоризации, вынося его в заголовок своего текста» [Михнюкевич]; О. В. Захарова провела подробный концептуальный анализ фольклорной основы «былин», задуманных Достоевским в переписке с Майковым [Захарова].

4 То, что Достоевский чувствовал себя не до конца уютно с поэтической стихией, показывают ряд его высказываний и его редкие собственные стихи (см. [Волгин]). Другого мнения о поэтическом даре Федора Михайловича Б. Н. Тихомиров, недавно посвятивший этой теме обширный труд (см. [Тихомиров]).

5 В этом отношении знаковым произведением для Достоевского была скорее всего «богатырская сказка» Н. М. Карамзина «Илья Муромец» (1795), написанная 4-стопным хореем с дактилическим окончанием.

6 Об активной творческой диалектике поэзии и прозы как литературном приеме в произведениях Достоевского см.: [Альми].

\section{Список литературы}

1. Алоэ С. Иванов Черт, Великий Инквизитор и «Агасвер» Кюхельбекера: об одном вероятном источнике «Братьев Карамазовых» // Достоевский: философское мышление, взгляд писателя / под ред. С. Алоэ. - СПб.: Дмитрий Буланин, 2012. - С. 191-220. (Dostoevsky Monographs; Вып. 3).

2. Альми И. Л. Роль стихотворных вставок в системе идеологического романа Достоевского // Альми И. Л. О поэзии и прозе. - СПб.: Скифия, 2002. - C. 446-463.

3. Бем А. Л. Фауст в творчестве Достоевского // О Достоевском. Сб. ст. / под ред. А. Л. Бема. - Paris: Amga editions, 1986. - С. 229-255. 
4. Волгин И. Л. «Стихи не твоя специальность...»: Достоевский как стихотворец // Волгин И. Л. Возвращение билета: парадоксы национального самосознания. - М.: Грантъ, 2004. - С. 173-179.

5. Гаспаров М. Л. Очерк истории русского стиха. - М.: Фортуна Лимитед, 2000. - $352 \mathrm{c}$.

6. Загидуллина М. В. Заимствование // Достоевский: эстетика и поэтика. Словарь-справочник / под ред. Г. К. Щенникова. - Челябинск: Металл, 1997. - C. 163.

7. Захаров В. Н. Система жанров Достоевского: типология и поэтика. Л.: Изд-во ЛГУ, 1985. - 209 с.

8. Захаров В. Н. Вставные жанры // Достоевский: эстетика и поэтика: словарь-справочник / под ред. Г. К. Щенникова. - Челябинск: Металл, 1997. - C. $145-146$.

9. Захаров В. Н. Имя автора - Достоевский: очерк творчества. - М.: Индрик, 2013. - 456 с.

10. Захарова О. В. Концепция былины у Ф. М. Достоевского // Проблемы исторической поэтики. - Петрозаводск: ПетрГУ, 2015. - Вып. 13. C. 271-285 [Электронный pecypc]. - URL: http://poetica.pro/files/ redaktor_pdf/1449828970.pdf (31.03.2019). DOI: 10.15393/j9.art.2015.3444

11. Иванов В. И. Байронизм, как событие в жизни русского духа // Иванов В. И. Собр. соч.: в 4 т. - Брюссель: Foyer Oriental Chretien, 1987. T. 4. - C. 282-286.

12. Ковач А. Иван Карамазов: Фауст или Мефистофель? // Достоевский. Материалы и исследования. - СПб.: Наука, 1997. - Т. 14. - С. 153-163.

13. Ковач А. Поэтика Достоевского / пер. с румынского Е. Логиновской. М.: Водолей Publishers, 2008. - 352 c.

14. Михнюкевич В. А. Былины // Достоевский: эстетика и поэтика: словарь-справочник / под ред. Г. К. Щенникова. - Челябинск: Металл, 1997. - C. 142.

15. Надъярных М. «Порочный список»: По, Бодлер, Достоевский. В мире слов и недомолвок Борхеса // По, Бодлер, Достоевский. Блеск и нищета национального гения / под ред. С. Фокина и А. Ураковой. - М.: НЛО, 2017. - C. 404-419.

16. Сараскина Л. И. Поэма о Великом инквизиторе как литературно-философская импровизация на заданную тему // Достоевский и мировая культура. - СПб.: Акрополь, 1996. - № 6. - С. 125-140.

17. Седельникова О. В. Ф. М. Достоевский и кружок Майковых. - Томск: Изд-во ТПУ, 2006. - 274 с.

18. Тихомиров Б. Н. Достоевский стихотворный // «Жил на свете таракан...»: стихи Ф. М. Достоевского и его персонажей. «Витязь горестной фигуры...»: Достоевский в стихах современников / сост., вступ. ст. и примеч., послесл. Б. Н. Тихомирова. - М.: Бослен, 2016. - С. 174-239.

19. Paolini S. Dostoevskij e il byronismo: osservazioni dalla pubblicistica e dal "Diario di uno scrittore" // Nuovi quaderni del CRIER. - Verona: Edizioni Fiorini, 2004. - Vol. 1. - P. 155-176. 


\title{
Stefano Aloe
}

The University of Verona (Università di Verona)

(Verona, Italy)

stefano.aloe@univr.it

\section{“These Are Not Only Poems...": Some Marginal Notes in the Letter of F. M. Dostoevsky to A. N. Maikov, Dated on May 15 (27), 1869}

\begin{abstract}
In his letter from Florence dated on 15th (27) May, 1869, F. M. Dostoevsky explains to Apollon Maikov a whole series of his ideas about both poetics and ideology. Some parts of the letter are devoted to the poetry and poetic genres, the fundamental pivotal points in Russian history and the problems of its explanation, atheism and Christianity which became a new centre of the writer's thoughts at that time. The article focuses on the concept of poetry that appears in the letter and, particularly, on the interpretation by Dostoevsky of the narrative and didactic character of the genre of "poem". Another important aspect of the analysis related to the previous one, concerns the study of a new narrative technique elaborated by Dostoevsky and consisting in a "quasi-artistical" description of the poetical writings. Dostoevsky never became a poet, but he could create poetical works in the same manner as his character Ivan Karamazov did adapting the subject of the "poem" about the Great Inquisitor. The originality of this approach is explained by the way of an artistic elaboration of the ideas and concepts inherent to Dostoevsky. In his letter to Maikov, as well as in Ivan's narration of the "poem" about the Great Inquisitor to Alyosha, there are seen the techniques of an extremely reduced, allusive manner of a creative process elaborated by Dostoevsky in his preparatory notebooks.
\end{abstract}

Keywords: F. M. Dostoevsky, A. N. Maikov, narratology, epistolary genre, The Great Inquisitor, poetic genres

About the author: Aloe Stefano - PhD, Professor of Slavonic Studies and Russian Literature, The University of Verona (Via San Francesco 22, Verona VR, 37129, Italy)

Received: February 18, 2019

Date of publication: September 9, 2019

For citation: Aloe S. “These Are Not Only Poems...”: Some Marginal Notes in the Letter of F. M. Dostoevsky to A. N. Maikov, Dated on May 15 (27), 1869. In: Problemy istoricheskoy poetiki [The Problems of Historical Poetics]. 2019, vol. 17, no. 3, pp. 86-105. DOI: 10.15393/j9.art.2019.6462 (In Russ.) 


\section{References}

1. Aloe S. Ivanov's Devil, The Grand Inquisitor and "Ahasuerus" of Küchelbecker: On one Probable Source of "The Brothers Karamazov". In: Dostoevskiy: filosofskoe myshlenie, vzglyad pisatelya [Dostoevsky: Philosophical Thinking, the Writer's View]. St. Petersburg, Dmitriy Bulanin Publ., 2012, pp. 191-220. (Dostoevsky Monographs; issue 3). (In Russ.)

2. Al'mi I. L. The Role of Poetic Inserts in the System of Dostoevsky's Ideological Novel. In: Al'mi I. L. O poezii i proze [Almi I. L. About Poetry and Prose]. St. Petersburg, Skifiya Publ., 2002, pp. 446-463. (In Russ.)

3. Bem A. L. Faust in Dostoevsky's Works. In: O Dostoevskom: sbornik statey [About Dostoevsky: Collection of Articles]. Paris, Amga editions Publ., 1986, pp. 229-255. (In Russ.)

4. Volgin I. L. "Poetry is not your Expertise...": Dostoevsky as a Poet. In: Volgin I. L. Vozvrashchenie bileta: paradoksy natsional'nogo samosoznaniya [Volgin I. L. The Return of the Ticket: Paradoxes of National Identity]. Moscow, Grant Publ., 2004, pp. 173-179. (In Russ.)

5. Gasparov M. L. Ocherk istorii russkogo stikha [An Essay on the History of Russian Verses]. Moscow, Fortuna Limited Publ., 2000. 352 p. (In Russ.)

6. Zagidullina M. V. Derivations. In: Dostoevskiy: estetika i poetika: slovar'-spravochnik [Dostoevsky: Aesthetics and Poetics: Dictionary and Reference Book]. Chelyabinsk, Metall Publ., 1997, p. 163 (In Russ.)

7. Zakharov V. N. Sistema zhanrov Dostoevskogo: tipologiya i poetika [The System of Genres of Dostoevsky: Typology and Poetics]. Leningrad, Pushkin Leningrad State University Publ., 1985. 209 p. (In Russ.)

8. Zakharov V. N. Inserted Genres. In: Dostoevskiy: estetika i poetika: slovar'-spravochnik [Dostoevsky: Aesthetics and Poetics: Dictionary and Reference Book]. Chelyabinsk, Metall Publ., 1997, pp. 145-146. (In Russ.)

9. Zakharov V. N. Imya avtora - Dostoevskiy: ocherk tvorchestva [The Author's Name is Dostoevsky: an Essay on the Creative Work]. Moscow, Indrik Publ., 2013. 456 p. (In Russ.)

10.Zakharova O. V. Dostoevsky's Conception of the Bylina. In: Problemy istoricheskoy poetiki [The Problems of Historical Poetics], Petrozavodsk, PetrSU Publ., 2015, issue 13, pp. 271-285. Available at: http://poetica.pro/files/ redaktor_pdf/1449828970.pdf (accessed on January 31, 2019). DOI: 10.15393/ j9.art.2015.3444 (In Russ.)

11. Ivanov V. I. The Byronism as an Event in Life of the Russian Spirit. In: Ivanov V. I. Sobranie sochineniy: $v 4$ tomakh [Ivanov V. I. Collected Works: in 4 Vols]. Bruxelles, Foyer Oriental Chretien Publ., 1987, vol. 4, pp. 282286. (In Russ.)

12. Kovács A. Ivan Karamazov: Faust or Mephistopheles? In: Dostoevskiy. Materialy i issledovaniya [Dostoevsky. Materials and Researches]. St. Petersburg, Nauka Publ., 1997, vol. 14, pp. 153-163. (In Russ.)

13. Kovács A. Poetika Dostoevskogo [Dostoevsky's Poetics]. Moscow, Vodoley Publishers, 2008. 352 p. (In Russ.) 
14. Mikhnyukevich V. A. Russian Epic Poems. In: Dostoevskiy: estetika i poetika: slovar'-spravochnik [Dostoevsky: Aesthetics and Poetics: Dictionary and Reference Book]. Chelyabinsk, Metall Publ., 1997, p. 142 (In Russ.)

15. Nad"yarnykh M. A "Vicious List": Po, Baudelaire, Dostoevsky. In the World of Borges' Words and Omissions. In: Po, Bodler, Dostoevskiy. Blesk i nishcheta natsional'nogo geniya [Po, Baudelaire, Dostoevsky. Splendors and Miseries of the National Genius]. Moscow, Novoe literaturnoe obozrenie Publ., 2017, pp. 404-419. (In Russ.)

16. Saraskina L. I. The Poem About the Grand Inquisitor as a Literary and Philosophical Improvisation on a Given Topic. In: Dostoevskiy i mirovaya kul'tura. Al'manakh [Dostoevsky and World Culture. Almanac]. St. Petersburg, Akropol' Publ., 1996, no. 6, pp. 125-140. (In Russ.)

17. Sedel'nikova O. V. F. M. Dostoevskiy i kruzhok Maykovykh [F. M. Dostoevsky and the Circle of the Maikovs]. Tomsk, Tomsk Polytechnic University Publ., 2006. 274 p. (In Russ.)

18. Tikhomirov B. N. "Zhil na svete tarakan....: stikhi F. M. Dostoevskogo i ego personazhey; "Vityaz' gorestnoy figury...»: Dostoevskiy v stikhakh sovremennikov ["Once Upon a Time There Lived a Cockroach...": Verses of F. M. Dostoevsky and of His Characters; "A Knight of a Grieving Figure...": Dostoevsky Through the Verses of His Contemporaries]. Moscow, Boslen Publ., 2017. 240 p. (In Russ.)

19. Paolini S. Dostoevskij e il byronismo: osservazioni dalla pubblicistica e dal "Diario di uno scrittore" [Dostoevsky and the Byronism: Remarks from the Publicistic Writings and "A Writer's Diary"]. In: Nuovi quaderni del CRIER. Verona, Edizioni Fiorini Publ., 2004, vol. 1, pp. 155-176. (In Italian) 